\title{
Socket Shield Technique- An Armour \& Boon to Implant
}

Dentistry

\author{
Swyeta GJ ${ }^{1 *}$, Vivek $\mathrm{G}^{2}$ and Amit $\mathrm{G}^{3}$ \\ ${ }^{1}$ Department of Periodontics \& Oral Implantology, ITS Centre for Dental Studies \& \\ Research, India \\ 2MDS Prosthodontist, Private Practitioner, India \\ ${ }^{3}$ Department of Oral and Maxillofacial Pathology and Microbiology, ITS Centre for \\ Dental Studies \& Research, India
}

\section{Review Article \\ Volume 2 Issue 4}

Received Date: October 23, 2017

Published Date: November 01, 2017

DOI: $10.23880 /$ oajds-16000152

*Corresponding author: Swyeta Jain Gupta, MDS, Department of Periodontics \& Oral Implantology, ITS Centre for Dental Studies \& Research, Ghaziabad, India, Postal Code: 201308, Tel: 9868236482; E-mail: dr.swyeta@gmail.com

\section{Abstract}

Healing of extraction sockets undergoes a re-modelling process which leads to horizontal and vertical bone loss. Alteration of ridge contour may compromise the restoration- oriented three dimensional positioning of the implant. Various methods of guided bone regeneration have been described to retain the original dimensions of the bone after extraction. In-lieu of surgical augmentation to correct a ridge defect, the socket-shield technique offers a promising solution. Socket shield technique has demonstrated the potential in preventing buccal bone from resorption in animal and clinical studies and may serve as a feasible treatment along with being cost effective and minimally invasive option in areas with high aesthetic concern.

Keywords: Immediate implant; Socket-shield technique

Abbreviations: SST: Socket-Shield Technique; PDL: Periodontal Ligament; RST: Root Submergence Technique

\section{Introduction}

Tooth eruption is ontogenetically related to alveolar bone formation [1]. Agenesis or ankylosis leads to reduced formation of the alveolar process [2,3]. Also, the loss of a tooth triggers a remodeling reaction as part of the healing process, involving various degrees of alveolar bone resorption, especially affecting the buccal lamella: The bundle bone is primarily vascularized by the periodontal membrane of the tooth. Therefore, this part of the alveolar bone is compromised by the extraction, to such an extent that the buccal lamella is insufficiently nourished, leading to its total or partial resorption $[4,5]$. Bone resorption of up to an average width of $50 \%$ [6] or $3.8 \mathrm{~mm}$ [7] has been reported. Losses in height of $2 \mathrm{~mm}$ to $4 \mathrm{~mm}$ [5-8] or $1.24 \mathrm{~mm}$ on average have also been measured. However, this resorption process is highly variable and not fully predictable [9]. A substantial $0.5 \%$ to $1 \%$ of the alveolar ridge volume is lost as the result of it [10]. A higher degree of resorption is to be expected in the presence of flap formation, thin soft tissue biotype and prominent roots, especially with frontal teeth in buccal position. Immediate implant placement does not necessarily prevent resorption of the alveolar ridge $[11,12]$. This process causes dimensional changes in the 


\section{Open Access Journal of Dental Sciences}

ridge and the aesthetic region is most affected by this process $[13,14]$. In order to overcome these negative consequences of tooth extraction various methods have been described in the literature such as hard and soft tissue augmentation following extraction with or without immediate implant placement [15]. Socket shield technique first described in 2010 aims at leaving the buccal fragment of root intact and placing implant on the lingual aspect of that fragment so that the tissues which remain in contact with the buccal fragment retain their vitality and prevent the ridge from collapsing thus improving the aesthetics especially during implant in the anterior maxillary region. The socket-shield (SS) technique provides a promising treatment adjunct to better manage these risks and preserve the postextraction tissues in aesthetically challenging Cases [16]. This technique can prove to be very helpful for implantologists when planning implants in aesthetic region.

\section{The Principle of Socket-Shield Technique [17]}

a) Preparation of the root of a tooth indicated for extraction in such manner that the buccal / facial root section remains in-situ with its physiologic relation to the buccal plate intact.

b) The tooth root section's periodontal attachment apparatus (periodontal ligament (PDL), attachment fibers, vascularization, root cementum, bundle bone, alveolar bone) remain vital and undamaged to prevents the expected post-extraction socket remodelling and to support the buccal / facial tissues.

c) The prepared tooth root section acts as a socket-shield and prevents the recession of tissues buccofacial to an immediately placed implant.

\section{Clinical Concept}

Based on this concept of root submergence technique (RST), submucosal root retention can virtually eliminate bone resorption, the retention and stabilization of the coronal and buccal bundle bone and the retention of the periodontal membrane by retaining a coronal tooth fragment (so-called "socket shield"), including adequate blood supply, can be expected [18]. To ensure complication-free healing, special attention should be paid to wound stabilization. Depending on the individual treatment plan of a patient, there is the option for immediate implant placement and to either wait for two to six months to allow for the formation of new bone, followed by implantation, or to leave the site without subsequent second procedure.

\section{Indications}

a) Vertical fractures of teeth without pulpal pathologies, where the tissue preservation and aesthetics are a priority.

b) Potential indications include their use as a part of delayed or late implantation approach or optimization of pontic support in crown bridge reconstructions or to improve the prosthesis base for removable dentures.

\section{Contraindications}

\section{General contraindications:}

i. All usual restrictions of oral surgical procedures:

ii. Bisphosphonate medication

iii.Immunosuppression

iv. Radiation therapy

v. Anti coagulation etc

Local contraindications: Absent buccal lamina which develops for instance after vertical root fractures or periodontitis.

\section{Step by Step Procedure}

a) Local anaesthesia should be administered. The crown of the tooth to be extracted is decoronated with a coarse-grained diamond bur.

b) The root of the tooth is sectioned mesiodistally with a long tapered fissure diamond bur coupled to a hydrated high-speed hand piece into facial and palatal halves followed by conservative extraction of the palatal root fragment using periotome, luxators and forceps preserving the facial root section unmanipulated and attached to the tooth socket.

c) Periotomes can be inserted between the palatal root section and the alveolar socket wall to severe the PDL and the section of root can then carefully delivered with so as not to disturb the facial root section.

d) The tooth socket's palatal wall and apex are then curetted to remove any tissue or infective remnants.

With the preparation steps complete, the tooth root hereafter was known as the socket-shield (SS). If planned for an immediate implant placement, an osteotomy is then sequentially prepared and a selected implant was inserted palatal to the socket shield. The gap between the shield and implant surface was left to enable blood clot formation.

\section{Sockets can be closed with sutures}

\section{Advantages}

a) Help ensure physiological preservation of labial and buccal bone structures if implant is placed in contact to 


\section{Open Access Journal of Dental Sciences}

the natural tooth fragment (shield) and prevent lamellar bone resorption.

b) Tissue preservation-preserves healthy periimplant tissues.

c) Buccal shield serves as a guiding structure when placing implants in optimum position.

d) Complete osseointergration can be achieved.

e) Formation of fibrous tissue around implant can be avoided.

f) Cost effective.

g) Minimal invasiveness.

h) Minimal material requirement (no bone substitute, GTR etc).

i) Offers a feasible option for vertically fractures teeth.

j) Helps maintain aesthetics.

\section{Disadvantages and limitations:}

a) Resorption associated with usual biological long term complication that may occur especially in the presence of pre existing or developing periodontal or endodontic infections or inflammations of the retained root fragments.

b) Technique sensitive. Displacement of buccal root fragment or even buccal lamellar bone.

c) Long term behaviour of the buccal shield has not yet been completely clarified.

\section{Conclusion}

Apart from affecting aesthetic outcome, alveolar ridge atrophy following tooth extraction has, above all a negative impact on the subsequent prosthetic or implant restoration. Ideally a method for preservation of alveolar ridge resorption should be cost effective and minimally invasive, with only minimal material requirements. However, these criterions are not entirely met by any of the methods available today. The targeted retention of root fragments via socket shield technique appears to be the only approach capable of achieving these criteria and complete alveolar ridge preservation. This technique avoids resorption of bundle bone by leaving a buccal root segment (socket shield) in place [19]. The socket shield technique provides a promising treatment adjunct to better manage the risks of extraction and preserve post extraction tissue in aesthetically challenging cases [8]. Further studies should test, whether the root fragments should be removed or if persisting, may lead to long term remodelling or resorption effects and long term results of this technique.

\section{Clinical Relevance}

The socket-shield technique (SST) represents an alternative approach to intervene remodeling and resorption processes by the maintenance of the facial part of the root during tooth extraction. The immediate placement of an implant supports the facial root fragment and thereby prevents a collapse of the buccal wall.

\section{References}

1. Schröder HE (1987) Orale Strukturbiologie. Georg Thieme Verlag: Stuttgart, Germany.

2. Eichenbaum IW (1977) Tooth eruption and ankylosis. J Prev Dent 4(5): 39-45.

3. Andersson L, Emami-Kristiansen Z, Högström J (2003) Single tooth implant treatment in the anterior region of the maxilla for treatment of tooth loss after trauma: A retrospective clinical and interview study. Dent Traumatol 19(3): 126-131.

4. Cardaropli G, Araújo MG, Lindhe J (2003) Dynamics of bone tissue formation in tooth extraction sites. An experimental study in dogs. J Clin Periodontol 30(9): 809-818.

5. Araújo MG, Lindhe J (2005) Dimensional ridge alterations following tooth extraction: An experimental study in the dog. J Periodontol 32(2): 212-218.

6. Schropp L, Wenzel A, Kostopoulos L, Karring T (2003) Bone healing and soft tissue contour changes following single-tooth extraction: A clinical and radiographic 12 -month prospective study. Int J Periodontics Restor Dent 23(4): 313-323.

7. Hämmerle CH, Araújo MG, Simion M (2012) Evidencebased knowledge on the biology and treatment of extraction sockets. Clin Oral Implant Res 23(5): 8082.

8. Botticelli D, Berglundh T, Lindhe J (2004) Hard-tissue alterations following immediate implant placement in extraction sites. J Periodontol 31(10): 820-828.

9. Nevins M, Camelo M, de Paoli S, Friedland B, Schenk RK et al. (2006) A study of the fate of the buccal wall of extraction sockets of teeth with prominent roots. J Periodontol 26(1): 19-29.

10. Carlsson GE, Persson G (1967) Morphologic changes of the manidible after extraction and wearing of dentures. A longitudinal clinical, and x-ray cephalometric study covering 5 years. Odontol Rev 18(1): 27-54. 


\section{Open Access Journal of Dental Sciences}

11. Chen ST, Wilson TG, Hämmerle CH (2004) Immediate or early placement of implants following tooth extraction: Review of biologic basis, clinical procedures, and outcomes. Int J Oral Maxillofac Implant 19: 12-25.

12. Araújo MG, Sukekava F, Wennström JL, Lindhe J (2005) Ridge alterations following implant placement in fresh extraction sockets: An experimental study in the dog. J Clin Periodontol 32(6): 645-652.

13. Hürzeler MB, Zuhr $O$, Schupbach $P$, Rebele SF, Emmanouilidis N, et al. (2010) The socket-shield technique: a proof-of-principle report. J Clin Periodontol 37(9): 855-862.

14. Wadhwani P, Goyal S, Tiwari S, Syed S, Paul T, et al. (2015) Socket Shield Technique: A New Concept of Ridge Preservation. Asian Journal of Oral Health \& Allied Sciences 5(2): 55.

15. Chen CL, Pan YH (2013) Socket Shield Technique for Ridge Preservation: A Case Re-port. J Prosthodont Implantol 2(2): 16-21.
16. Davarpanah M, Szmukler-Moncler S (2009) Unconventional implant treatment: I. Implant placement in contact with ankylosed root fragments. A series of five case reports. Clin Oral Implants Res Aug 20(8): 851-856.

17. Gluckman H, Du Toit J, Salama M (2015) The socket shield technique to support the buccofacial tissues at immediate implant placement. International dentistry-african edition 5(3).

18. Glocker M, Attin T, Schmidlin PR (2014) Ridge preservation with modified "socket-shield" technique: a methodological case series. Dentistry Journal 2(1): 11-21.

19. Bäumer D, Zuhr O, Rebele S, Schneider D, Schupbach $P$, et al. (2015) The socket-shield technique: histological, clinical, and volumetrical observations after separation of the buccal tooth segment-a pilot study. Clin Implant Dent Relat Res 17(1): 71-82. 